*ak RMIS View/Frint Document Cover Sheet tow

This document was retrieved from the Documentation and Records Manaqement (DRM) ISEARCH System. It is intended for Information only and may not be the most recent or updated version. Contact a Document Service Center (see Hanford Info for locations) if you need additional retrieval information.

Accession \#: D196079162

Document \#: SD-EN-WAP-005

Title/Desc:

WASTE ANALYSIS PLAN FORT PLANT COMPLEX

Pages: 55 


\begin{tabular}{|l|l|}
\hline $\begin{array}{l}\text { 2. To: (Receiving Organization) } \\
\text { Distribution }\end{array}$ & $\begin{array}{l}\text { 3. From: coriginating Organization) } \\
\text { T Plant, Env. Mgn \& Training }\end{array}$ \\
\hline $\begin{array}{l}\text { 5. Proj./Prog./Dept./Div.: } \\
87470 / 241170\end{array}$ & 6. cog. Engr.: \\
\hline
\end{tabular}

8. Originator Remarks:

N/A
4. Related EDT NO.:

$N / A$

7. Purchase Order No.:

N/A

9. Equip./Component No.:

$N / A$

10. System/Bldg./Facility:

T Plant Complex

11. Receiver Remarks:

N/A
12. Major Assm. Dwg. No.: $N / A$

13. Permit/Permit Application No.: $N / A$

14. Required Response Date: ASAP

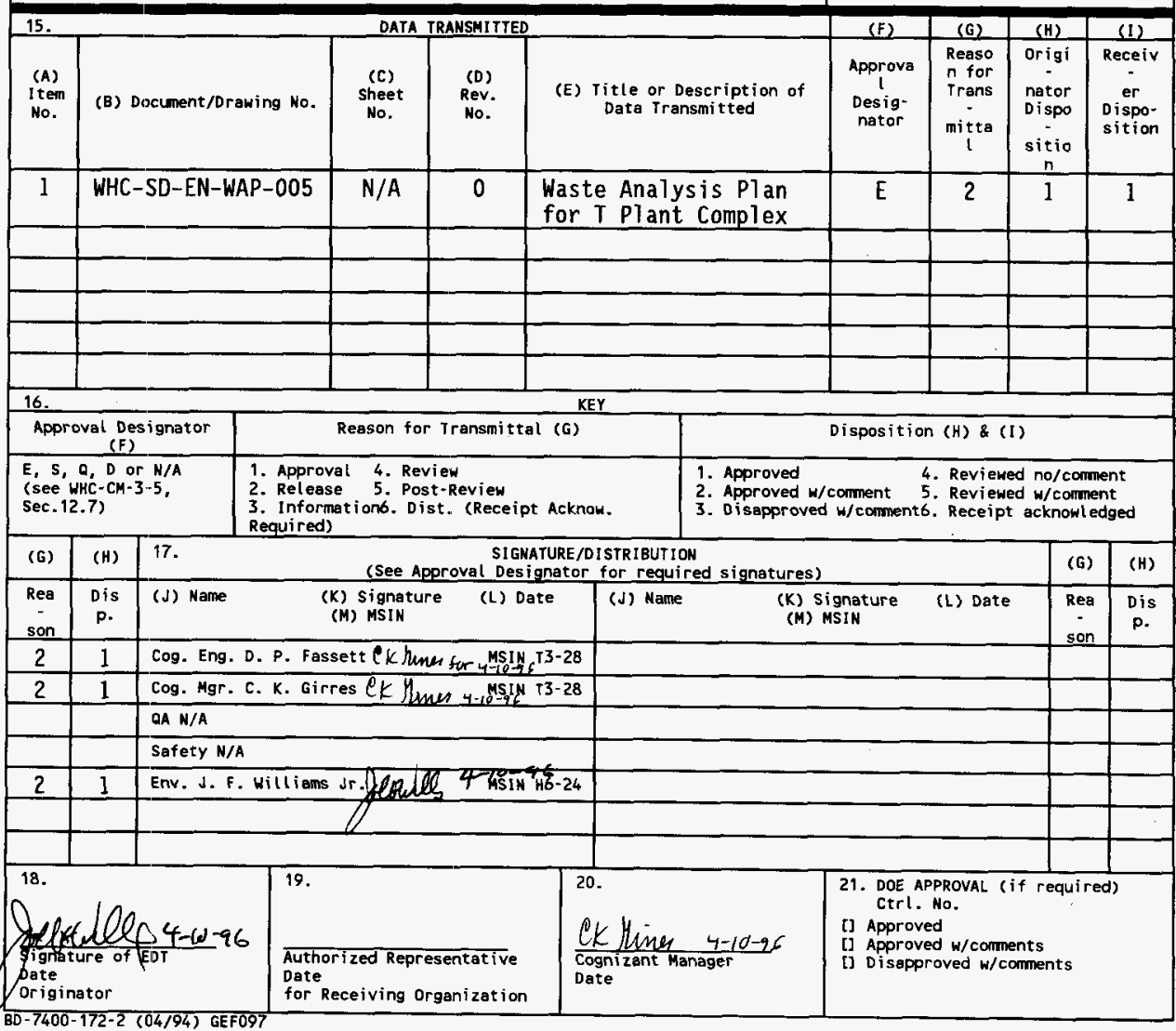




\section{Waste Analysis Plan for T Plant Complex}

\section{J. F. Williams Jr.}

Westinghouse Hanford Company, Richland, WA 99352

U.S. Department of Energy Contract DE-ACO6-87RL10930

\section{EDT/ECN: $615710 \quad$ UC: 630 \\ Org Code: $01822 \quad$ Charge Code: E41170 \\ B\&R Code: EW3130020 Total Pages: 52}

Key Words: T Plant Complex, Hanford Facility

Abstract: Washington Administration Code 173-303-300 requires that a waste analysis plan (WAP) be provided by a treatment, storage, and/or disposal (TSD) unit to confirm their knowledge about a dangerous and/or mixed waste to ensure that the waste is managed properly. The specific objectives of the WAP are as follows:

- Ensure safe management of waste during treatment and storage

- Ensure that waste generated during operational activities is properly designated in accordance with regulatory requirements

- Provide chemical and physical analysis of representative samples of the waste stored for characterization and/or verification before the waste is transferred to another TSD unit

- Ensure compliance with land disposal restriction (LDR) requirements for treated waste

- Provide basis for work plans that describes waste analysis for development of new treatment technologies.

TRADEMARK DISCLAIMER. Reference herein to any specific commercial product, process, or service by trade name, trademark, manufacturer, or otherwise, does not necessarily constitute or imply its endorsement, recommendation, or favoring by the United States Goverment or any agency thereof or its contractors or subcontractors.

Printed in the United States of America. To obtain copies of this document, contact: UHC/BCS Document Control Services, P.O. Box 1970, Mailstop H6-08, Richland WA 99352, Phone (509) 372-2420; Fax (509) 376-4989.
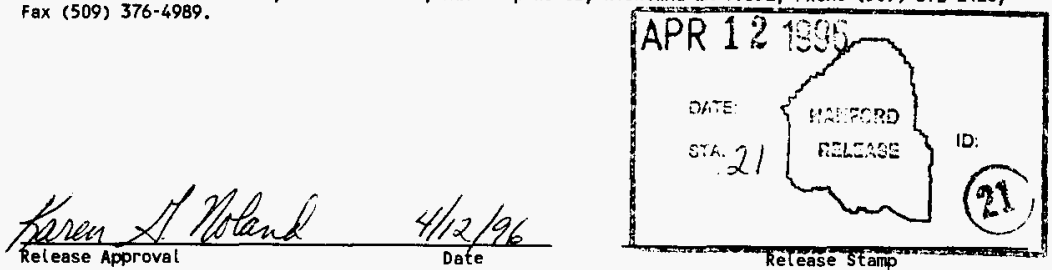

Approved for Public Release 
WHC-SD-EN-WAP-005, Rev. 0

GLOSSARY

METRIC CONVERSION CHART

\section{CONTENTS}

1.0 FACILITY DESCRIPTION . . . . . . . . . . . . . . . . . 1-1

1.1 CONTAINER TREATMENT AND/OR STORAGE .............. . . . . . 1 - 1

1.2 TANK STORAGE AND TREATMENT .................. . . . $1-2$

1.3 CONTAINMENT BUILDINGS . . . . . . . . . . . . . . 1-2

2.0 WASTE ACCEPTANCE PROGRAM .................... . . . 2-1

2.1 WASTE ACCEPTED AT T PLANT COMPLEX ............... . . . $2-1$

2.2 WASTE ACCEPTANCE AND TRANSFER PROCEDURES ............

2.2.1 Offsite Generator and/or Onsite Generating Unit

Responsibilities................ . 2-2

2.2.2 T Plant Complex Tracking and/or Manifest . . . . . . . 2-2

2.2.3 Process for Unacceptable Waste........... . 2-3

2.3 WASTE CHARACTERIZATION ................. 2-4

2.3.1 Sampling Procedures ... . . . . . . . . . . . 2-4

2.3.2 Analytical Methods . . . . . . . . . . . . . . 2-5

2.3.3 Frequency of Waste Characterization . . . . . . . 2-5

2.4 WASTE ANALYSIS REQUIREMENTS PERTAINING TO LAND DISPOSAL

RESTRICTIONS ..................... 2-6

2.4.1 Waste Characterization . . . . . . . . . . . . . 2-6

2.4.2 Sampling and Analytical Procedures.......... . 2-7

2.4.3 Frequency of Analysis .............. . 2-7

2.4.4 Notifications and Certifications .......... . . 2-7

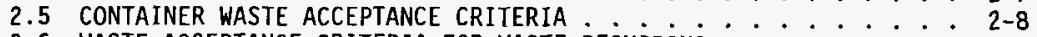

2.6 WASTE ACCEPTANCE CRITERIA FOR WASTE REQUIRING

CHARACTERIZATION . . . . . . . . . . . . . . . . . 2-9

2.7 WASTE VERIFICATION ........................ 2 . . . . .

3.0 WASTE ANALYSIS FOR SUSPECT WASTE, DIFFICULT WASTE, AND SPILLS . . . 3-1

3.1 WASTE ANALYSIS FOR SUSPECT WASTE ............. . . 3-1

3.1.1 Waste Management Processes . . . . . . . . . . . . . . 3-1

3.1.2 Waste Analysis Processes for Suspect Waste...... 3-2

3.2 WASTE ANALYSIS FOR SPILLS ................ . . . . . $3-2$

4.0 CHARACTERIZATION OF WASTE GENERATED AND TREATED AT

T PLANT COMPLEX ......................... . . . 4-1

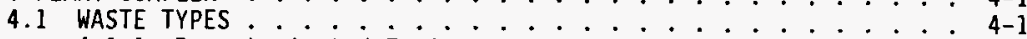

4.1.1 Decontaminated Equipment . . . . . . . . . . . $4-1$

4.1.2 Decontamination Waste .............. . . . 4-2

4.1.3 Maintenance Waste . . . . . . . . . . . . . . . 4 4

4.1 .4 Treatment Waste........... . . . . . . . 4

4.2 SAMPLING AND ANALYSIS OF THE DIFFERENT WASTE TYPES $. . . . .44-4$

4.2.1 Characterization Parameters and Rationale . . . . . . . 4-4

4.2.2 Characterization of Treated Waste ......... . 4 4 4

4.2.3 Sampling Procedures ............... 4-5 


\author{
CONTENTS (cont)
}

\begin{abstract}
4.2.4 Analytical Methods ............. 4-7
4.2.5 Frequency of Samp 7 ing and Analysis . . . . 4-8

4.3 NOTIFICATION REQUIREMENTS PERTAINING TO LAND DISPOSAL

RESTRICTIONS FOR DEBRIS . . . . . . . . . . . 4-8

4.3.1 Notification Requirements for Debris . . . . . 4-9

4.3.2 Notification Requirements for Waste Streams . . . . 4-9

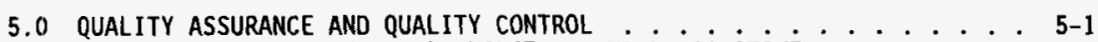

5.1 QUALITY ASSURANCE AND QUALITY CONTROL OBJECTIVES . . . . . 5-1

5.2 SAMPLING, COLLECTION, AND ANALYTICAL OBJECTIVES ...... . 5-2

5.2.1 Sampling objectives . . . . . . . 5-2

5.2.2 Data Collection and Analytical objectives . . . 5-2

5.3 FIELD QUALITY ASSURANCE AND QUALITY CONTROL ....... $5-3$

5.4 LABORATORY QUALITY ASSURANCE AND QUALITY CONTROL ...... 5-3

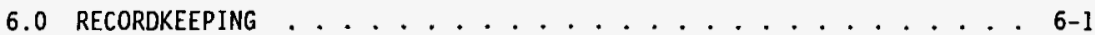

6.1 WASTE ANALYSIS PLAN RECORDS .............. 6-1

6.2 LAND DISPOSAL RESTRICTION RECORDS $\ldots \ldots \ldots$

6.3 WASTE ANALYSIS PLAN MAINTENANCE AND REVISION $\ldots \ldots . \ldots 6-2$

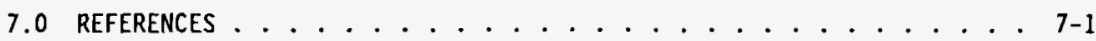

\title{
ATTACHMENTS
}

1 ANALYTICAL PARAMETERS, METHODS, AND RATIONALE FOR WASTE . . . ATT 1-i

2 FIELD AND LABORATORY ANALYTICAL METHODS FOR VERIFICATION

FIMGERPRINT SAMPLING ........................ ATT 2-i

\section{FIGURE}

1-1. T Plant Complex (Configuration as of December 1995) . . . . . . F1-1 
WHC-SD-EN-WAP-005, Rev. 0

$\begin{array}{ll}\text { ACRONYMS AND ABBREVIATIONS } \\ \text { CFR } \\ \text { COLIWASA } & \begin{array}{l}\text { Code of Federal Regulations } \\ \text { composite liquid waste sampler }\end{array} \\ \text { DQO } & \text { data quality objectives } \\ \text { DST } & \text { double-shell tank } \\ \text { EHW } & \text { extremely hazardous waste } \\ \text { EPA } & \text { U.S. Environmental Protection Agency } \\ \text { LDR } & \text { land disposal restrictions } \\ \text { MSCIS } & \text { material safety data sheet } \\ \text { QA } & \text { quality assurance } \\ \text { QC } & \text { quality control } \\ \text { RCRA } & \text { Resource Conservation and Recovery Act of } 1976 \\ \text { TSD } & \text { treatment, storage and/or disposal } \\ \text { WAC } & \text { Washington Administrative Code }\end{array}$


WHC-SD-EN-WAP-005, Rev. 0

1

2

3

4

5

6

7

8

10

11

12

13

14

15

16

17

18

19

20

21

22

23

24

25

26

27

28

29

30

31

32

33

34

35

36

37

38

39
METRIC CONYERSION CHART

Into metric units

Out of metric units

\begin{tabular}{|c|c|c|c|c|c|}
\hline If you know & $\begin{array}{c}\text { Multiply } \\
\text { by }\end{array}$ & To get & If you know & $\begin{array}{c}\text { Multiply } \\
\text { by }\end{array}$ & To get \\
\hline \multicolumn{3}{|c|}{ Length } & \multicolumn{3}{|c|}{ Length } \\
\hline inches & 25.40 & millimeters & millimeters & 0.0393 & inches \\
\hline inches & 2.54 & centimeters & centimeters & 0.393 & inches \\
\hline feet & 0.3048 & meters & meters & 3.2808 & feet \\
\hline$y$ ards & 0.914 & meters & meters & 1.09 & yards \\
\hline miles & 1.609 & kilometers & kilometers & 0.62 & miles \\
\hline \multicolumn{3}{|c|}{ Area } & \multicolumn{3}{|c|}{ Area } \\
\hline $\begin{array}{l}\text { square } \\
\text { inches }\end{array}$ & $6.45 \overline{16}$ & $\begin{array}{l}\text { square } \\
\text { cent imeters }\end{array}$ & $\begin{array}{l}\text { square } \\
\text { cent imeters }\end{array}$ & 0.155 & $\begin{array}{l}\text { square } \\
\text { inches }\end{array}$ \\
\hline square feet & 0.092 & $\begin{array}{l}\text { square } \\
\text { meters }\end{array}$ & $\begin{array}{l}\text { square } \\
\text { meters }\end{array}$ & 10.7639 & $\begin{array}{l}\text { square } \\
\text { feet }\end{array}$ \\
\hline $\begin{array}{l}\text { square } \\
\text { yards }\end{array}$ & 0.836 & $\begin{array}{l}\text { square } \\
\text { meters }\end{array}$ & $\begin{array}{l}\text { square } \\
\text { meters }\end{array}$ & 1.20 & $\begin{array}{l}\text { square } \\
\text { yards }\end{array}$ \\
\hline $\begin{array}{l}\text { square } \\
\text { miles }\end{array}$ & 2.59 & $\begin{array}{l}\text { square } \\
\text { kilometers }\end{array}$ & $\begin{array}{l}\text { square } \\
\text { kilometers }\end{array}$ & 0.39 & $\begin{array}{l}\text { square } \\
\text { miles }\end{array}$ \\
\hline acres & 0.404 & hectares & hectares & 2.471 & acres \\
\hline \multicolumn{3}{|c|}{ Mass (weight) } & \multicolumn{3}{|c|}{ Mass (weight) } \\
\hline ounces & 28.35 & grams & grams & 0.0352 & ounces \\
\hline pounds & 0.453 & kilograms & kilograms & 2.2046 & pounds \\
\hline short ton & 0.907 & metric ton & metric ton & 1.10 & short ton \\
\hline \multicolumn{3}{|c|}{ Volume } & \multicolumn{3}{|c|}{ Volume } \\
\hline $\begin{array}{l}\text { fluid } \\
\text { ounces }\end{array}$ & 29.57 & milliliters & milliliters & 0.03 & $\begin{array}{l}\text { fluid } \\
\text { ounces }\end{array}$ \\
\hline quarts & 0.95 & Titers & Titers & 1.057 & quarts \\
\hline gallons & 3.79 & Titers & Titers & 0.26 & gallons \\
\hline cubic feet & 0.03 & $\begin{array}{l}\text { cubic } \\
\text { meters }\end{array}$ & $\begin{array}{l}\text { cubic } \\
\text { meters }\end{array}$ & 35.3147 & cubic feet \\
\hline cubic yards & $0 . \overline{76}$ & $\begin{array}{l}\text { cubic } \\
\text { meters }\end{array}$ & $\begin{array}{l}\text { cubic } \\
\text { meters }\end{array}$ & 1.308 & $\begin{array}{l}\text { cubic } \\
\text { yards }\end{array}$ \\
\hline \multicolumn{3}{|c|}{ Temperature } & \multicolumn{3}{|c|}{ Temperature } \\
\hline Fahrenheit & $\begin{array}{l}\text { subtract } \\
32 \text { then } \\
\text { multiply } \\
\text { by } 5 / 9 \text { ths }\end{array}$ & Celsius & Celsius & $\begin{array}{l}\text { multiply } \\
\text { by } \\
9 / 5 \text { ths, } \\
\text { then add } \\
32\end{array}$ & Fahrenheit \\
\hline \multicolumn{3}{|c|}{ Force } & \multicolumn{3}{|c|}{ Force } \\
\hline $\begin{array}{l}\text { pounds per } \\
\text { square inch }\end{array}$ & 6.895 & kilopascals & kilopascals & 0.15 & $\begin{array}{l}\text { pounds per } \\
\text { square } \\
\text { inch }\end{array}$ \\
\hline
\end{tabular}

Source: Engineering Unit Conversions, M. R. Lindeburg, PE., Second Ed., 1990, Professional Publications, Inc., Belmont, California. 


\subsection{FACILITY DESCRIPTION}

The T Plant Complex is located in the 200 West Area of the Hanford Facility, Richland, Washington. The T Plant Complex consists of two main structures, the 221-T Building and 2706-T Building (includes 2706-TA), and various support structures and storage units within the $T$ Plant Complex (Figure 1-1). The 221-T and 2706-T Buildings are used for the storage (tank, container, and equipment) and treatment (tank, container, and equipment) of dangerous and/or mixed waste before transfer to an onsite treatment, storage, and/or disposal (TSD) unit or offsite TSD facility (hereinafter referred to as another TSD unit). The 221-T Building, 2706-T Building, various support structures, and storage units are used for storage, staging of containerized waste, decontamination activities, sampling, assay (radiological screening), characterization, verification, repackaging, and treatment of dangerous and/or mixed waste received from TSD units and offsite generators.

The specific objectives of the waste analysis plan are as follows:

- Ensure safe management of waste during treatment and storage

- Ensure that waste generated during operational activities is properly designated in accordance with regulatory requirements

- Provide chemical and physical analysis of representative samples of the waste stored for characterization and/or verification before the waste is transferred to another TSO unit

- Ensure compliance with land disposal restriction (LDR) requirements for treated waste

- Provide basis for work plans that describes waste analysis for development of new treatment technologies.

Because dangerous waste does not include the source, special nuclear, and by-product material components of mixed waste, radionuclides are not within the scope of this document. Information on radionuclides is provided only for general knowledge where appropriate.

\subsection{CONTAINER TREATMENT AND/OR STORAGE}

Dangerous and/or mixed waste is transferred to $T$ P1 ant Complex for storage until assay, verification, sampling, analysis, characterization, repackaging, and/or treatment has been completed. Treatment and storage of dry and 7 iquid dangerous and/or mixed waste in containers occurs in the 221-T Building deck and in various locations. The 214-T Building also is used for treatment, storage, and overpacking of dangerous and/or mixed waste containers.

Waste transferred to T Plant Complex can be staged in one of the storage areas designated for greater-than-90-day storage. Waste is staged in these 
WHC-SD-EN-WAP-005, Rev. 0

storage areas until assay, verification, sampling, analysis, characterization, repackaging, and/or treatment is accomplished and the waste is transferred to another TSD unit.

\subsection{TANK STORAGE AND TREATMENT}

Equipment received at T Plant Complex can be of two types: (1) equipment to be decontaminated for reuse and returned to service and (2) equipment received as waste, to be decontaminated to make the equipment amenable for disposal as solid, dangerous, mixed, or radioactive waste. Equipment is decontaminated in the 2706-T and 221-T Buildings using steam, high pressure water, chemicals, and other physical surface abrasion methods. Some of the equipment meant for reuse cannot be returned to service because of unsuccessful radiological decontamination, inability to repair the equipment, or other reasons. If the equipment has been successfully decontaminated but is no longer in usable condition, the equipment can be dispositioned for material recycling (e.g., for metals recovery) or for disposal as solid waste. Equipment that is not completely decontaminated is sent to another TSD unit for treatment, storage, and/or disposal, depending on the nature of the waste.

Liquid mixed waste generated during decontamination activities in the 221-T Building is collected in a series of stainless steel tanks. These tanks are designated $6-1,5-6,5-7,5-9,11-R$, and 15-1. Liquid mixed waste is stored and can be pH or nitrite adjusted in tank 15-1. The waste is pumped into a railcar and transferred to another TSD unit for treatment and/or storage.

Liquid mixed waste generated during decontamination activities in the 2706-T Building is collected in the railroad pit in the building and pumped through a double-lined stainless steel underground pipeline to the 211-T collection sump located southeast of the 2706-T Building. The liquid waste is transferred from the 221-T collection sump to the 221-T Building liquid mixed waste handling system by underground pipeline.

Sludge from the decontamination activities accumulate in the bottoms of the stainless steel tanks in the 221-T Building, 2706-T Building railroad pit, and the 211-T collection sump. This sludge is stored in the tanks until the waste is required to be transferred to another TSD unit. When the sludge is ready for transfer, the waste is characterized, treated, and/or packaged in waste containers for transfer to another TSD unit.

\subsection{CONTAINMENT BUILDINGS}

The 221-T and 2706-T Buildings serve as containment buildings for waste management activities at $\mathrm{T}$ Plant Complex. Waste or equipment can be stored in these areas until treatment and/or processing is accomplished. Waste processing includes activities such as assay, verification, sampling and analysis, characterization, waste repackaging, and/or treatment. The 221-T Building canyon deck and railroad tunnel and 2706-T Building are used 52 for these activities. 
1 Treatment could include decontamination of contaminated equipment, 2 material decontamination, and processing of waste containers. Equipment 3 awaiting treatment could be stored at the 221-T Building deck and cells. The 4 amount and type of equipment in the cells varies with treatment support

5 requirements. The $2706-T$ Building is used to decontaminate railroad cars, 6 buses, trucks, automobiles, heavy equipment, process equipment, and other 7 materials. Waste equipment and containers are stored in the building while 8 awaiting processing. 
WHC-SD-EN-WAP-005, Rev. 0

This page intentionally left blank. 


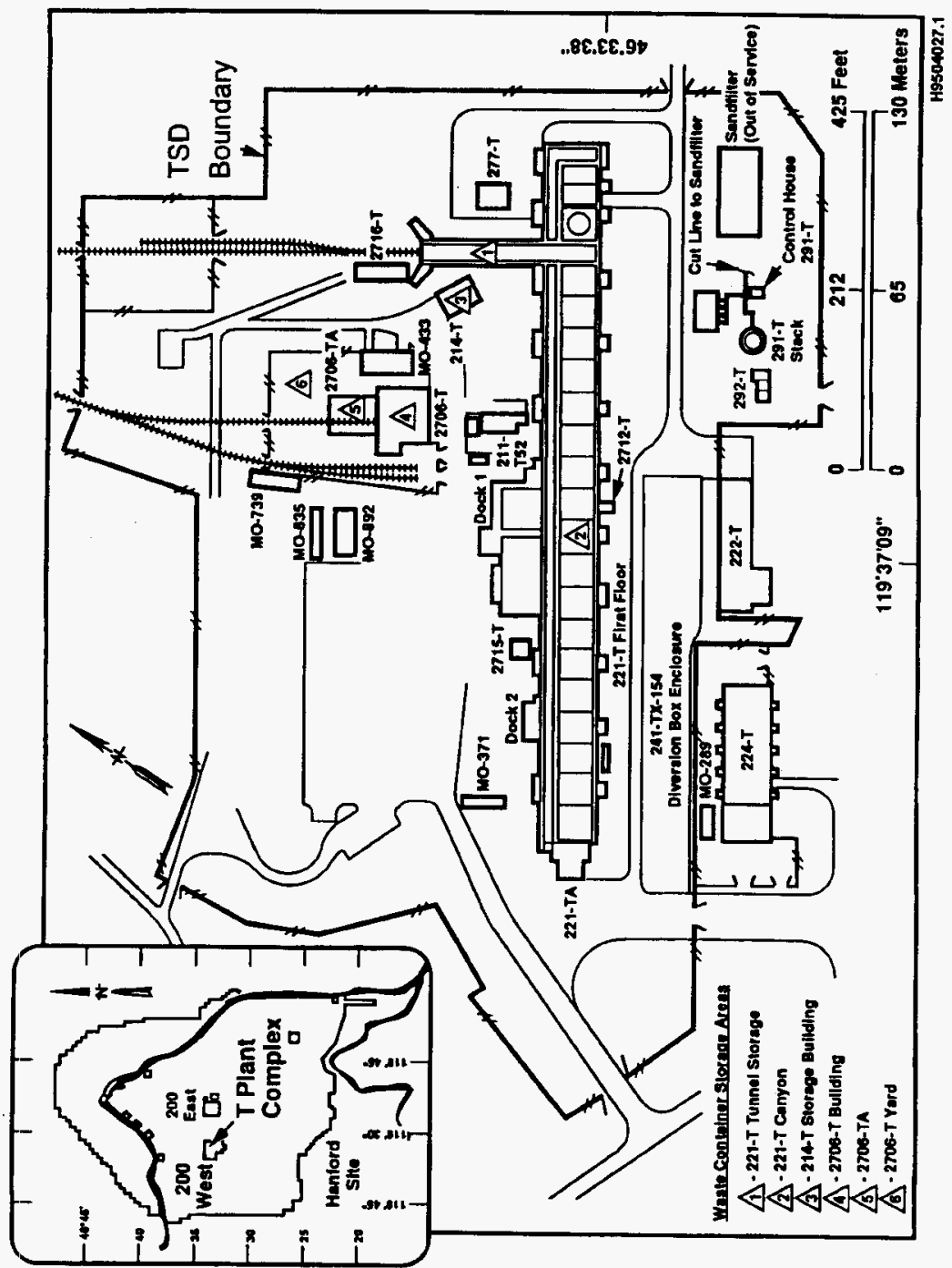

Figure 1-1. T Plant Complex (configuration as of December 1995). 
WHC-SD-EN-WAP-005, Rev. 0

\subsection{WASTE ACCEPTANCE PROGRAM}

The T Plant Complex accepts a wide range of waste types for treatment and/or storage. This section provides the waste acceptance process for the proper management of waste.

\subsection{WASTE ACCEPTED AT T PLANT COMPLEX}

Dangerous and/or mixed waste contaminated equipment is accepted at $T$ Plant Complex where the equipment is decontaminated and either reused or subsequently transferred for disposal. The $T$ Plant Complex also accepts equipment for decontamination and stores liquid and solid residues generated by decontamination activities in tank systems. The liquid and solid residues could contain contaminants in the following categories:

- Corrosive

- Reactive

- Ignitable

- Toxicity characteristic

- F-listed

- State-only (WAC 173-303).

Dangerous and/or mixed waste is accepted from other TSD units for storage while awaiting assay, sampling, verification, analysis, characterization, repackaging, and/or treatment.

The 221-T and 2706-T Buildings provide dangerous and/or mixed waste decontamination, reclamation, and decommissioning services for process equipment. The characteristics of each waste stream that could be stored in the T Plant Complex can be divided into the following waste categories:

- Corrosive

- Reactive

- Ignitable

- Toxicity characteristic

- F-listed

- Discarded chemical products

- State-only (WAC 173-303).

The following section provides waste acceptance criteria.

\subsection{WASTE ACCEPTANCE AND TRANSFER PROCEDURES}

Offsite generators and/or onsite generating units must provide basic information on waste characteristics to $\mathrm{T}$ Plant Complex before waste acceptance is considered. The $T$ Plant Complex reviews the information provided and makes a determination on whether the information is adequate and whether to accept the waste. After completion of acceptance documentation, the waste can be transferred. 
WHC-SD-EN-WAP-005, Rev. 0

\section{2.2.1 Offsite Generator and/or Onsite Generating Unit Responsibilities}

2

The offsite generator submits their initial request to the U.S. Department of Energy, Richland Operations Office (DOE-RL). The onsite generating unit requests approval from $T$ Plant Complex to transfer waste by submitting a waste handling and treatment request form. The $T$ Plant Complex reviews the information provided in the waste handling and treatment request form and accompanying data including waste characterization information and package description. The T Plant Complex compares the data to the waste acceptance criteria to determine whether the waste is described adequately and whether the waste can be accepted. The T Plant Complex also determines whether process knowledge provided in lieu of analytical data is adequate. The $T$ Plant Complex determines whether or not to accept the waste based on the information on the waste handling and treatment request form.

The following information must be provided to $T$ Plant Complex before acceptance of the waste:

- Description of the waste generation process

- For routine transfers of a certain waste stream, descriptions of waste generation processes when modifications are made

- Description of the waste including physical description, available chemical analyses, expected dangerous constituents, and waste numbers

- For routine transfers of a certain waste stream, descriptions of chemical usage changes, which could cause changes in the waste characteristics

- Description of the waste packaging (including waste contents, filler or components other than waste, container/liner, expected size, volume, weight, and quantity)

- LDR notification information.

\subsubsection{T Plant Complex Tracking and/or Manifest}

Before unloading the waste, waste tracking papers and waste packages are inspected to ensure the following conditions are met.

- A11 necessary waste tracking forms for the waste are present and completed correctly.

- A11 documents are signed and dated.

- A1l waste packages are accounted for and correctly indicated on the waste tracking forms.

- Waste containers are in sound condition (i.e., free of holes, punctures, major dents) and structural integrity is not compromised. 
WHC-SD-EN-WAP-005, Rev. 0

- Waste containers are labeled and marked as indicated on the waste tracking forms (i.e., package identification numbers, weights, waste numbers, etc. on the waste tracking forms are the same as those on the containers).

- Containers do not contain waste that is incompatible with other containers or waste in the area where the waste is staged.

Section 2.2.3 describes the actions taken should $T$ Plant Complex receive a waste package that is determined to be unacceptable.

After waste receipt, the waste containers are unloaded and staged in an appropriate designated area. Containers are staged with not less than a 76-centimeter space between each double row of containers to facilitate inspections.

Waste containers transferred to and from the staging area require completion of a waste container transfer form. Copies of the signed waste container transfer form are maintained at $T$ Plant Complex.

\subsubsection{Process for Unacceptable Waste}

If during the pre-acceptance inspection a waste package is determined to be unacceptable, the offsite generator and/or onsite generating unit is notified. The $\mathrm{T}$ Plant Complex requests that written instructions be provided to allow personnel to correct the conditions. In those cases where the waste is acceptable, but documentation is incorrect, the offsite generator and/or onsite generating unit is notified to correct the documentation. Waste may be rejected and returned if an agreement on correcting the conditions is not reached. Instances of noncompliance with the waste acceptance criteria and documentation requirements are recorded and tracked by $\mathrm{T} P$ lant Complex compliance personnel.

If a noncompliant waste package is not returnable because of its condition or packaging, and agreement on disposition cannot be reached between involved parties, the waste package will be isolated at $T$ Plant complex pending resolution. The issue will be referred to DOE-RL, Washington State Department of Ecology (Ecology), and other appropriate regulatory agencies as necessary for resolution.

For offsite generators, the DOE-RL provides notification to Ecology of any unreconciled manifest discrepancies that are not resolved within 15 days. Discrepancies for onsite generating units are handled internally.

\subsection{WASTE CHARACTERIZATION}

Offsite generators and/or onsite generating units provide the physical, chemical, and radioactive characteristics of dangerous and/or mixed waste received for each process conducted at $\mathrm{T}$ Plant Complex, except for waste types described in Section 3.0. Offsite generators and/or onsite generating units 
WHC-SD-EN-WAP-005, Rev. 0

1 can use chemical analyses or process knowledge to determine waste

2 characteristics.

3

If process knowledge is used in the characterization process, a complete description of the process generating the waste [e.g., original product material safety data sheets (MSDS)] and published characterization methodology on the specific waste stream and/or characterization methodology on similar waste streams must be provided. Field analysis can be used to confirm process knowledge.

If adequate process knowledge exists to ensure a particular constituent is not present in the waste, there is no requirement to analyze for that constituent. However, the waste certification summary must establish that there is no reason to suspect the constituent is in the waste. This can be accomplished by including a detailed process description and/or published data of the process.

\subsubsection{Sampling Procedures}

Because of physical variations in the waste received at $T$ Plant complex, sampling methodologies differ for different waste streams and also differ because of offsite generator and/or onsite generating unit needs. Sampling methods, equipment, containers, and parameters will adhere to guidance provided in Test Methods for Evaluating Solid Waste, Physical/Chemical Methods (SW-846) (EPA 1986), or other EPA-approved methods.

The offsite generator and/or onsite generating unit determines the appropriate sampling method, conducts all field and sampling QA/QC, arranges for and coordinates with appropriate analytical laboratories, and documents the sampling and analysis activities. The offsite generator and/or onsite generating unit must certify that the waste analysis information is complete and accurate.

The offsite generator and/or onsite generating unit also document the sampling activities, chain of custody, and arranges sample transfer. Sampling information, custody records, and analytical results are maintained by the offsite generator and/or onsite generating unit.

Sampling methods are designed to ensure that each sample is accounted for at all times. The primary objectives of sample control are as follows.

- Each sample received for analysis is uniquety identified with a sample identification number.

- Correct samples are analyzed and are traceable to the applicable data records.

- Sample collectors prepare a permanent log of sampling activities.

- Important and necessary sample constituents are preserved. 
WHC-SD-EN-WAP-005, Rev. 0

- Offsite generators and/or onsite generating units ensure that all samples are labeled with identifying information.

- Samples are protected from loss, damage, or tampering.

- Any alteration of samples during collection or transfer (e.g., filtration, preservation, breakage) is documented.

- A record of sample custody and integrity is established that will withstand legal scrutiny.

- A chain-of-custody record accompanies samples at all times.

All sample collection, preparation, packaging, transportation, and analys is conforms to the requirements of SW-846 or other EPA-approved methods, unless radiological concerns require alternative methods because of safety issues.

\subsubsection{Analytical Methods}

Attachment 1 lists typical analytical methods the offsite generators and/or onsite generating units could use in characterizing waste. To the extent possible, test methods are those specified in SW-846. Where alternate methods are used, e.g., for highly radioactive samples, methods are described in the quality assurance plan of the laboratory performing the analysis.

The offsite generator and/or onsite generating unit could characterize the waste based on chemical data, MSDS, or other process-related information in lieu of analysis. However, T Plant Complex personnel will require waste sampling and analysis in conformance with this waste analysis.plan, if the data provided in lieu of analysis are determined to be inadequate.

\subsubsection{Frequency of Waste Characterization}

All recurrent waste streams received by $T$ Plant Complex are recharacterized by the generating unit at least annually. As in the original characterization process, recharacterization can involve evaluation of process knowledge or sampling and analysis. A number of waste streams accepted by $T$ Plant Complex could be generated on an irregular or one-time basis. Each such new waste stream is characterized before acceptance, or by using the procedures in Section 3.0 for suspect and difficult waste ${ }^{2}$.

1 Suspect waste is defined as waste that is 'suspected' to be contaminated with regulated constituents.

2 Difficult waste is defined as mixed waste that cannot receive a complete chemical and/or radiological analysis in the 90-day time allowed by regulation. The acceptance criteria limits the storage time for difficult waste to an additional 90 days after acceptance into the difficult waste management program. 
WHC-SD-EN-WAP-005, Rev. 0

1

2

3

40

More frequent characterization of waste types would be conducted under the following circumstances.

- A new waste stream is generated.

- The waste generating process changes significantly.

- The waste characteristics are highly variable from transfer to transfer.

- The waste is physically or chemically unstable.

- The waste characterization is suspect (e.g., when waste numbers for the same waste stream are reported inconsistently, or when the offsite generator and/or onsite generating unit routinely provides waste numbers inconsistent with information on the transfer papers, analytical data, MSDS, or other information).

\subsection{WASTE ANALYSIS REQUIREMENTS PERTAINING TO LAND DISPOSAL RESTRICTIONS}

The Hazardous and Solid Waste Amendments of 1984 prohibit land disposal of certain types of waste. The T P1 ant Complex treats and stores LDR waste. The T Plant Complex also provides interim storage for dangerous and/or mixed waste destined for further treatment, storage, and/or disposal. Information presented in this section describes how offsite generators and/or onsite generating units characterize, document, and certify waste subject to LDR requirements.

\subsubsection{Waste Characterization}

For all waste being accepted at $T$ Plant Complex, the offsite generators and/or onsite generating units are required to document waste characteristics, the level of toxicity characteristics, and the presence of listed waste. This information allows the offsite generators and/or onsite generating units to accurately make all LDR determinations and to complete all required notifications and certifications.

\subsubsection{Sampling and Analytical Procedures}

The LDR waste streams must be analyzed for all constituents listed in 40 CFR 268.48 that reasonably would be expected to be in the waste streams. The typical analytical methods are EPA-approved and are presented in Attachment 1.

\subsubsection{Frequency of Analysis}


WHC-SD-EN-WAP-005, Rev. 0

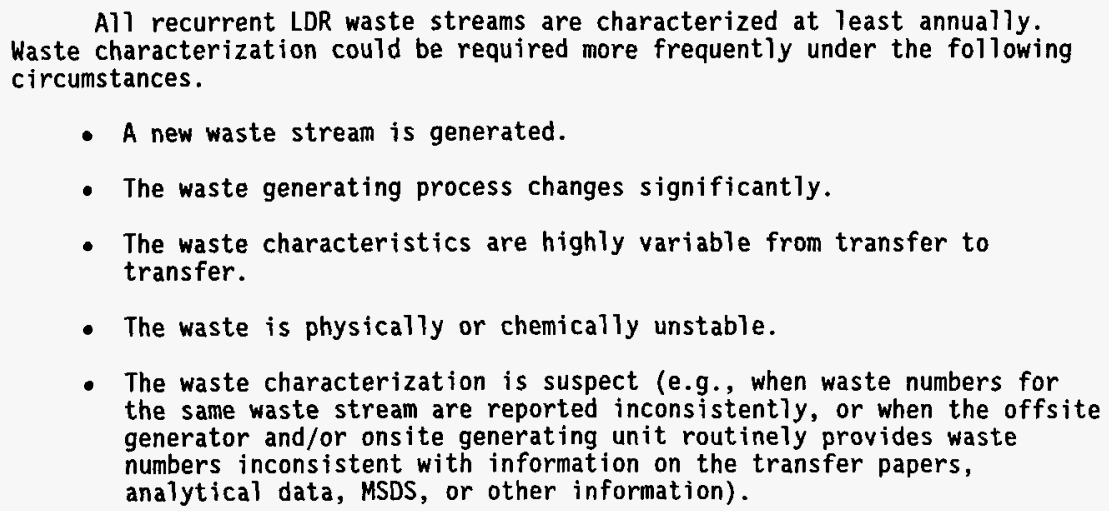

A11 recurrent LDR waste streams are characterized at least annually. Waste characterization could be required more frequently under the following circumstances.

- A new waste stream is generated.

- The waste generating process changes significantly.

- The waste characteristics are highly variable from transfer to transfer.

- The waste is physically or chemically unstable.

- The waste characterization is suspect (e.g., when waste numbers for the same waste stream are reported inconsistently, or when the offsite generator and/or onsite generating unit routinely provides waste numbers inconsistent with information on the transfer papers, analytical data, MSDS, or other information).

\subsubsection{Notifications and Certifications}

For LDR waste that is treated and/or stored, the offsite generator and/or onsite generating unit are required to provide the following LDR information:

- Dangerous waste numbers

- Available waste analysis

- The corresponding treatment standards set forth in 40 CFR 268, Subpart $C$, and all applicable prohibitions

- Information contained in the notifications and certifications required under 40 CFR 268.7 .

If the waste transferred is restricted, but meets the applicable treatment standard(s), the offsite generator and/or onsite generating unit must submit the same notification information listed previously, and a certification stating that the waste meets all applicable treatment standards. If the waste does not meet the applicable treatment standards, a notification stating this fact is provided with the information listed previously.

A waste tracking system is in place to document the transfer of waste, including waste subject to LDRs. Records related to treatment and disposal of waste subject to LORs are maintained by the generating unit in the operating record as required by 40 CFR 264.73 (b) (10) and (12).

\subsection{CONTAINER WASTE ACCEPTANCE CRITERIA}

The $T$ Plant Complex could receive waste containers that are improperly packaged to sample or repackage the contents based on agreement with offsite 
generators and/or onsite generating units. However, the ultimate

responsibility for waste characterization resides with the offsite generators 3 and/or onsite generating units. Any waste that violates the waste acceptance 4 criteria will be returned to the generator and/or will be isolated until the 5 waste acceptance conflict is resolved.

Dangerous and/or mixed waste must be packaged in compatible and approved containers. Cardboard, fiberboard, paper, cloth, burlap, rubber, or glass for outer packaging is prohibited unless such packaging is specified for a certain waste. Improperly packaged waste might be received at $\mathrm{T}$ PIant Complex to be repackaged. However, waste with a dangerous waste number other than the numbers identified in the Part $A$, Form 3, permit application (DOE/RL-88-21) is not accepted for treatment and/or storage.

Leaking, punctured, or dented containers, or containers with visible compromises in integrity are not the responsibility of $T$ Plant Complex and might not be accepted. If the containers are accepted, the containers are separated and overpacked immediately. Accepting future waste from the offsite generator and/or onsite generating unit that transferred the damaged container might not occur until the issue is resolved.

The T Plant Complex will not accept waste unless the following conditions are met or there is a previous agreement with the offsite generator and/or onsite generating unit to repackage the waste.

- Incompatible waste must not be packaged within the same container. Containers of incompatible materials must not be placed on the same pallet for movement within a storage area.

- Corrosive liquids must be packaged in metal containers with compatible liners or approved polyethylene containers.

- Cyanide- and sulfide-bearing waste solutions must have a $\mathrm{pH}$ of greater than 9.

- Internal packaging, absorbents, etc., generally must be noncombustible unless approved lab packs or materials are used.

- A minimum 10\% ullage (84 millimeters or 21 liters for a 208-1iter container) must be left when filling containers with liquid.

- Bung plugs or caps must be properly gasketed and tightened securely to prevent leakage.

\subsection{WASTE ACCEPTANCE CRITERIA FOR WASTE REQUIRING CHARACTERIZATION}

The T Plant Complex accepts dangerous, mixed, suspect, and/or difficult waste requiring verification and/or characterization. Containers of suspect waste and difficult waste must be accompanied by appropriate waste tracking forms. 
WHC-SD-EN-WAP-005, Rev. 0

1

2

3

Any waste that is received for verification or characterization is isolated in a storage area and appropriately labeled until verification or characterization can be performed. The appropriate $T$ Plant Complex personnel have the responsibility and authority to evaluate waste following verification for compliance with the waste acceptance criteria and to determine any required corrective action. Waste analys is methods used for characterization of suspect waste are provided in Section 3.0.

\subsection{WASTE VERIFICATION}

It might be necessary to verify that the contents of a waste package match associated documentation. Waste verification could include opening a waste package, looking at the contents, or removing the contents and inspecting the contents. Field screening instrumentation could be used when a container is opened to identify hazards to personnel. Field screening also might confirm the presence of a certain waste that is expected to be present. The waste is compared to documentation to ensure the waste that is visually identified is described. Discarded chemical products with "P" and "U" waste numbers that are containerized in overpack containers are verified using MSDS information. Waste verification activities are documented in a waste verification logbook and are maintained as part of the T Plant complex operating record.

It might be necessary to sample waste to determine the following.

- Documentation associated with the waste package is accurate and complete.

- Waste meets the waste acceptance criteria.

- Waste is packaged correctiy.

- The waste is what is expected to be.

- Waste adequately is characterized to allow necessary processing or disposal.

The verification sampling and analysis performed on waste could be limited or thorough depending on existing information, the needs of the offsite generator and/or onsite generating unit, and the type of waste processing that is needed. In general, knowledge of levels of dangerous waste constituents present in waste is required. If process knowledge indicates there is no possibility that certain constituents are present in the waste, it is not necessary to sample and analyze for all dangerous waste constituents. However, if the waste is suspect, sampling and analys is would be required, using SW-846 methods. As with the waste handling activities that are performed, a major consideration in selecting analytical methods and parameters is the needs of the responsible offsite generator and/or onsite generating unit. The containers are sampled using the analytical methods listed in Attachment 1 . 
The results of waste verification and sampling and analysis will be used to determine whether waste should be repackaged. If requested, $T$ P 7 ant 3 Complex personnel will repackage the waste.

Fingerprint ${ }^{1}$ analysis for selected parameters might be appropriate for a sample if there is extensive process knowledge or if there is comprehensive analytical data for a container of waste. The EPA allows fingerprint analysis to provide an indication of whether the waste has been identified accurately on the waste tracking forms, LDR notification/certification, pre-acceptance contract, or other documentation. The containers are sampled using the analytical methods listed in Attachment 2.

For waste packages accepted at T Plant Complex, at least 5 percent or an alternative rate based on process knowledge and/or analytical data must be verified.

Verification is performed using a combination of nondestructive examination, physical examination, and/or chemical screening. Exceptions to chemical sampling include the following 'special materials':

- Waste packages precluded from opening because of as low as reasonably achievable (ALARA)

- Empty product containers

- Single substance spill material

- Off-specification, contaminated, and/or outdated commercial products in the original product container

- Contaminated debris and asbestos (does not include liquids or soils)

- Other special-case situations handied on a case-by-case basis.

Special materials have been exempted from chemical screening because these materials potentially are hazardous materials (e.g., remote handled, asbestos); are well defined and nonvariable (e.g., single substance spill material or off-specification products); or are unusualiy difficult to sample and analyze (e.g., empty product containers, contaminated debris, or demolition materials). For these exceptions, the onsite generating unit or offsite generator supplies sufficient chemical and physical characteristics for proper disposal of the waste.

1 'Fingerprint' parameters are those parameters that will confirm process knowledge, i.e., a container is labeled 'corrosive', and states that the waste contains sodium hydroxide; therefore, the waste will be tested for sodium and $\mathrm{pH}$ to confirm that process knowledge is correct. 
WHC-SD-EN-WAP-005, Rev. 0

This page intentionally left blank. 
WHC-SD-EN-WAP-005, Rev. 0

\subsubsection{Waste Management Processes}

Containers of suspect waste and difficult waste accepted at $T$ P lant Complex require waste tracking forms. The suspect and difficult waste will be isolated until completely characterized.

Containers received at storage areas are verified to ensure that the paperwork and container match. Transfer labels and placards are compared with the waste tracking forms. Each container is inspected for damage and external contamination in the staging area. Contaminated containers are wrapped in plastic or overpacked and moved to a cleaning area. Containers are surveyed for potential surface radiological contamination. The following sequence establishes generic waste handling precautions; work plans for specific waste will identify additional precautions to be taken.

- The health physics technician ensures appropriate levels of protective clothing are donned by the personnel before performing the work.

- If the containers are metal drums or metal boxes, the 1 id is removed with a nonsparking tool, and the container is evaluated for hazardous or flammable vapors.

- The health physics technician samples the inside of the lid for radiological contamination and determines the conditions for proceeding.

- If crystalline material is noted on any object within a container, the object is considered shock-sensitive. All container handling ceases until the material is determined by the hazardous materials team not to be shock-sensitive. 
- When repackaging is necessary, waste within a container is segregated and packaged according to the required treatment.

- All mixed waste containers are packaged, inventoried, and identified.

- If unknown liquids or suspect solids are encountered, a sample of the waste could be taken.

If discrepancies or deficiencies are found, these will be resolved before the waste manifest/waste tracking form is signed by the T Plant Complex. If discrepancies cannot be resolved, the $T$ Plant Complex either rejects the entire waste shipment/transfer or rejects only those containers associated with the discrepancies (refer to Section 2.2.3).

\subsubsection{Waste Analysis Processes for Suspect Waste}

Waste preferentially is designated using process knowledge or other information (e.g., MSDS) provided on the waste tracking form. Typically, suspect waste cannot be designated adequately using process knowledge; therefore a representative sample is taken (Section 4.0).

Characteristics that cannot be determined by process knowledge will be sampled and analyzed per applicable criteria (Attachment 1). Attachment 1 provides the analyses to be performed, the rationale for the performance of each analysis, and the analytical method to be used. Sample analysis results are used to identify constituents that would prohibit disposal in a landfill.

Field analyses will be performed to determine characteristics necessary to manage the waste. Other sampling will be performed to complete characterizations.

\subsection{WASTE ANALYSIS FOR SPILLS}

If a leak or spill is discovered within T Plant Complex that cannot be tracked to a specific container (and associated waste characterization information), the contingency plan will be implemented. The residues of such a release would be sampled and analyzed in accordance with the requirements in the process described in Section 3.1.2 to determine the characteristics of the waste residue as defined by waste designation procedures in WAC 173-303. 
WHC-SD-EN-WAP-005, Rev. 0

\subsection{CHARACTERIZATION OF WASTE GENERATED AND tREATED AT T PLANT COMPLEX}

The T Plant Complex operations generate the following waste types:

- Decontaminated equipment that cannot be returned to service

- Liquid, sludge, and solid waste from decontamination activities

- Maintenance waste

- Treatment waste.

Some contaminated equipment at $T$ Plant Complex might not be returned to service if the equipment is unable to be repaired, decontamination efforts are unsuccessful, or the equipment is unsuited for service in some other way. In these cases, the effectiveness of the decontamination process will dictate whether the unusable equipment will be discarded as dangerous, mixed, radiological, or solid waste, or recycled for metal recovery. The majority of the equipment to be decontaminated at $\mathrm{T}$ Plant Complex will be returned to service after successful decontamination.

Waste generated from decontamination operations performed on useable or unusable equipment includes solid and liquid material. Water, steam, sand, and various chemicals are examples of liquids and solids media that might be used to remove contamination from equipment. Contamination removed from equipment with liquid might be in a liquid or sludge form. Dirt, grease, and various chemical and radiological materials are examples of solid contaminants that could be removed from equipment.

Various waste types are generated by routine maintenance activities at T Plant Complex as follows:

- Materials that contact regulated chemical products

- Unused or old chemical products that will not be used

- Various materials that could be regulated because of chemical content.

The T Plant Complex treats waste in containers to stabilize or neutralize the waste and treats waste equipment to meet debris rule criteria. Addition of absorbent material, grouting/encapsulation, stabilization, and $\mathrm{pH}$ neutralization are examples of treatments. The characteristics of the containerized waste might be changed after treatment.

\subsection{WASTE TYPES}

The following sections describe the types of materials that will be decontaminated or treated and sampled.

\subsubsection{Decontaminated Equipment}

The majority of equipment contaminated with dangerous or mixed waste that is accepted at T Plant Complex for decontamination will be returned to service. This equipment is not considered waste after decontamination is 
1 successfully completed, and it is not addressed further by this waste analysis

2 plan. Some of the equipment that is contaminated with dangerous or mixed

3 waste will not be returned to service because the contamination has not been 4 sufficiently removed, the equipment cannot be repaired, or it is in some other 5 way unsuited for service. At this time the equipment will be declared waste 6 and managed appropriately.

\subsubsection{Decontamination Waste}

Waste resulting from decontamination activities can be divided into three waste streams: (1) liquid mixed waste stored in tanks, (2) sludge that accumulates in tanks and is stored in the tanks, and (3) solid waste resulting from the nonaqueous decontamination processes (e.g., sand blasting, solid carbon dioxide blasting). The discussions in the subsequent sections apply to all three streams unless specifically stated otherwise.

Liquid mixed waste from decontamination activities in the 2706-T Building is accumulated in the railroad pit. From the railroad pit, the liquid mixed waste is pumped to the 211-T collection sump located southeast of the 2706-T Building. The liquid mixed waste is transferred from the 211-T collection sump to the 221-T Building mixed waste handling system by underground pipeline (refer to Section 1.2).

Liquid mixed waste from decontamination activities in the 2706- $T$ and 221-T Buildings accumulates in a series of stainless steel tanks including tanks $6-1,5-6,5-7,5-9,11-R$, and 15-1. From tank 15-1, the waste is characterized and pumped to a railroad tank car and transferred to another TSD unit.

The decontamination waste collected in T Plant Complex tanks has two phases; liquid and settled sludge. These waste streams typically are mixed waste, but could include dangerous or radioactive waste. The liquid waste stream is predominantly water that could contain various contaminants. The sludge is a heavy viscous emulsion generally composed of water slurries containing sandblast sands, dirt, oils, and soaps. Decontamination efforts could include use of relatively dilute acidic and caustic solutions, steam, water, detergents, hydrocarbons, and abrasives. Equipment that is accepted for decontamination could contain chemical constituents such as oils, greases, and other hydrocarbons. Painted equipment could have heavy metal-bearing flakes of paint; plastics could add phthalates; and wood material could add other solvent-based paints and preservatives to the collection tanks. When sludge accumulation requires removal, the solids that accumulate in the bottoms of these tanks are characterized, placed in containers, and transferred to another TSD unit.

The third waste stream from decontamination activities is a solid material that might be dangerous, mixed, or radioactive waste. This waste stream is a result of the residuals from nonaqueous decontamination processes such as sandblasting or carbon dioxide blasting, use of rags, and use of absorbent pads. The waste is collected, characterized, and stored in containers and transferred to another TSD unit. 
WHC-SD-EN-WAP-005, Rev. 0

The three waste streams are characterized based on process knowledge and on sampling and analysis. Sampling and analysis are conducted as described in Section 5.2.1 through 5.2.5.

\subsubsection{Maintenance Waste}

Various waste streams are generated during the performance of maintenance activities. This waste includes cloth, paper, rubber, concrete, glass, and contaminated equipment that might have come into contact with dangerous or mixed waste. Also included in this category are waste solvents in aerosol cans, high-efficiency particulate air filters, lead-containing paint waste, and routine maintenance waste. If process knowledge is insufficient to properly characterize the maintenance waste, sampling and analys is is performed before the waste is transferred to another TSD unit. The T PI ant Complex ensures that characterization of the maintenance waste is sufficient to demonstrate compliance with the waste acceptance criteria of the TSD unit to which the waste will be transferred.

\subsubsection{Treatment Waste}

Treatment waste is produced when waste is treated at T Plant complex. Contaminated equipment could be treated by applying an immobilization technology to the equipment and associated contamination. Immobilization technologies could include macro-encapsulation, micro-encapsulation, and sealing. Size reduction of equipment might be necessary to perform treatment on equipment. Certification statements will be completed when appropriate treatment methods are used for equipment and the Alternative Treatment Standards for Hazardous Debris (40 CFR 268.45) are met. Containerized waste could be treated in containers or removed from the containers before treatment and returned to the containers. In addition to the waste that is being treated, various waste streams are generated during the performance of treatment activities. This waste could include cloth, paper, rubber, concrete, and glass.

The debris treatment standards (40 CFR 268.45) most likely to be implemented at T Plant Complex include the physical extraction methods of abrasive blasting and high pressure steam and water sprays, and the chemical extraction methods of water washing and spraying. These extraction technologies have a performance standard of a 'clean debris surface' for metal, glass, plastic, and rubber.

"A clean debris surface means the surface, when viewed without magnification, shall be free of all visible contaminated soil and hazardous waste except that residual staining from soil and waste consisting of light shadows, slight streaks, or minor discolorations, and soil and waste in cracks, crevices, and pits may be present provided that such staining and waste and soil in cracks, crevices, and pits shall be limited to no more than 5 percent of each square inch of surface area" (40 CFR 268.45). 
WHC-SD-EN-WAP-005, Rev. 0

2

\subsection{SAMPLING AND ANALYSIS OF THE DIFFERENT WASTE TYPES}

The following sections describe the sampling procedures and the analyses that will be performed.

\subsubsection{Characterization Parameters and Rationale}

The parameters that are used to characterize the dangerous and/or mixed waste streams are selected to meet the objectives of designating the waste, providing for safe handling of the waste, meeting acceptance criteria at the receiving TSD unit, and meeting LDR requirements. Waste generated at $T$ Plant Complex is characterized using process knowledge to the extent possible. Attachment 1 identifies the parameters, methods, and rationale that are used to complete characterization of the dangerous and/or mixed waste streams if process knowledge is insufficient.

Maintenance waste generally is completely characterized using process knowledge. Because maintenance waste is derived from known materials, process knowledge should be sufficient to characterize the waste. Sampling and analysis is used only if process knowledge is not adequate to characterize the waste, or the process producing the waste is not rigidly controlled. Maintenance waste is characterized sufficiently to meet regulatory requirements and to meet the acceptance criteria of the receiving TSD unit.

Solid equipment or debris treatment (decontamination) waste is best characterized using a combination of process knowledge and sampling and analysis. The solid equipment or debris treatment waste is expected to contain the contaminants that were present on the equipment or debris. However, the concentrations of contaminants will be unknown and there could be uncertainties in the range of contaminants. Therefore, sampling and analysis might be used to complete characterization of the solid treatment waste. Sampling and analysis also will be performed on treated waste, when necessary, to show compliance with treatment standards.

Liquid and sludge tanks waste will be characterized by sampling and analysis in cases where use of process knowledge is impracticable.

\subsubsection{Characterization of Treated Waste}

Containerized waste that has been treated at $\mathrm{T} P \mathrm{Pl}$ ant might be sampled to verify that treatment was successful. The sampling and associated analysis for treated containerized waste might only address prohibited or restricted constituent concentrations or waste characteristics for which the waste was treated. A more thorough analysis of treated containerized waste is unnecessary because waste received at $\mathrm{T}$ Plant Complex should have been characterized by the offsite waste generator and/or onsite generating unit.

Equipment or debris could be treated or decontaminated sufficiently to be reused. Equipment or debris that is useable and has been treated sufficiently to be reused might undergo field screening or limited sampling and analysis. 
Limited characterization of useable material might be needed to ensure that contaminant levels do not pose a health or safety risk and the equipment can be used for its intended purpose. However, material that is to be reused does not require thorough characterization.

Contaminated equipment or debris that is not functional or cannot be sufficiently treated for reuse will be declared waste that requires characterization and/or treatment. This equipment will be characterized primarily using process knowledge because of the difficulty of collecting representative samples. The waste could be treated before being transferred to another TSD unit. Equipment or debris that has been treated successfully using methods specified in regulatory requirements generally will not be sampled.

Sampling treated containerized waste or contaminated equipment is not necessary if technology based standards or alternative treatment standards are applied to the waste. Alternative treatment standards might apply to contaminated equipment that meets the definition of debris in 40 CFR 268 and has been treated using EPA specified methods. Technology based standards might apply to non-debris or containerized waste that has been treated using EPA specified methods. Documentation including a certification is prepared to show that technology based standards or alternative treatment standards apply to a treated waste and the waste treatment meets regulatory requirements.

\subsubsection{Sampling Procedures}

Sampling information, chain-of-custody records, and analytical results are submitted as part of the data package supporting waste characterization. Sampling methods are designed to ensure that each sample is accounted for at all times. The primary objectives of the sample control methods are as follows:

- Each sample received for analysis is uniquely identified.

- The correct samples are analyzed and are traceable to the applicable data records.

- Important and necessary sample constituents are preserved.

- Samples are protected from loss, damage, or tampering.

- Any alteration of samples during collection or transfer (e.g., filtration, preservation, breakage) is documented.

- A record of sample custody and integrity is established that will satisfy legal scrutiny.

The appropriate T Plant Complex personnel is responsible for arranging all sampling and laboratory support for sample analysis. Samples are processed at one of several laboratories qualified to perform analysis of waste samples. When the purpose of sample analysis is to designate waste, 
WHC-SD-EN-WAP-005, Rev. 0

sampling and analytical methods used are in accordance with EPA SW-846 methods (EPA 1986) or other methods approved by Ecology.

The basic sampling sequence is as follows:

- Obtain sample number from the laboratory and complete the sample tag before sampling

- Obtain a precleaned sampler and sample bottles

- Attach sample label to sample bottles

- For sampling liquid waste, lower a sampler to obtain a representative sample of the waste liquid to be obtained. If the waste does not appear to be homogeneous, sample each stratified layer

- For sampling tank sludge, drag a sampling device along the bottom of the tank to collect sludge. Lift the sample device and decant excess water before filling sample bottles

- For sampling solid waste, use a scoop, trier, or hand auger to obtain a sample of the waste. For large containers of waste, composite several augers or scoops to ensure samples are representative

- Fill sample containers in the following sequence: volatile organics, semivolatile organics, metals, ignitability, $\mathrm{pH}$ (corrosivity)

- For liquid and sludge waste, rinse exterior surfaces of sample bottles with water and wipe with a dry rag

- For solid waste, wipe the exterior surfaces of the sample bottles with a dry rag

- Double bag sample bottles in plastic bags and seal each bag with tape

- Attach sample labels to outer plastic bags

- Place samples in a durable ice-filled cooler or comparable receptacle for transfer to the laboratory

- Complete the chain-of-custody forms

- Review all documentation and enclose the forms in a leaktight, polyethylene bag taped to the underside of the cooler lid

- Seal and mark the coolers or comparable receptacles in accordance with onsite requirements

- Transfer coolers to the analytical laboratory within 24 hours of collection 


\subsubsection{Analytical Methods}

Attachment I lists the analytical methods used to determine the characteristics of the waste generated during decontamination, maintenance,

- A unique identifier

- Date, time, and location of collection

- Sampie coliector's name

- Preservatives used

- Analyses requested.

Sample collectors prepare a permanent log of sampling activities. The $\log$ entries include as appropriate: date of collection, time of collection, location, batch number, sample number, tank number, copy of the chain-of-custody form, sampling methodology, container description, waste matrix ( 1 iquid), description of generating process (e.g., decontamination activities), number and volume of samples, field observations, field measurements (e.g., $\mathrm{pH}$, percent lower explosive limit), laboratory destination and laboratory number, and signature of collector. These logs entries are made by the appropriate T Plant Complex personnel while the sampling is performed. The logs or copies of them are maintained by the appropriate $T$ Plant Complex personnel after completion of sampling activities.

A chain-of-custody record accompanies samples at all times. The record contains the sample number, date and time of collection, sample type, sample location, methods of transfer, and signatures of the collector and all subsequent custodians.

A11 equipment used to sample waste material is disposable or designed for easy decontamination. Contaminated disposable equipment is managed as dangerous waste as appropriate. Cleanable equipment is decontaminated thoroughly before reuse or return to central sampling equipment decontamination area.

During all sampling activities, strict compliance with industrial hygiene and safety standards is mandatory. Personnel are required to wear eye, skin, and respiratory protection as dictated by the health physics technician or by requirements. If samplers accidentally contact waste material, decontamination is immediately performed.

Transportation of samples is in accordance with all applicable requirements. Dangerous and/or mixed waste samples are packaged properly, marked, and labeled. Waste tracking forms are prepared. 
WHC-SD-EN-WAP-005, Rev, 0

and other treatment activities. To the extent possible, analytical test

methods will be those specified by the EPA (1986).

As previously discussed, waste can be characterized based on chemical data, materials profiles, or other process-related information in addition to analysis.

\subsubsection{Frequency of Sampling and Ana1ysis}

Liquid mixed waste from treatment and/or decontamination activities is sampled from tank 15-1 before waste transfer to the DST System (DOE/RL-90-38). If after a minimum of four sampling events, the results of the analyses indicate variation of less than 25 percent in the sample population (as measured by the coefficient of variation), the sampling frequency can be reduced to not less than once a year. event.

sludge in tanks is sampled, at a minimum, before each sludge removal

The solid dangerous and/or mixed waste from decontamination, maintenance, and other treatment is sampled as necessary to ensure accurate designation before transfer of the waste.

Sampling and analysis will be required under the following circumstances.

- Process knowledge is inadequate.

- A new waste stream is accepted for decontamination.

- The waste generating process for a given waste stream changes.

- The waste characteristics are highly variable from transfer to transfer for a specific offsite generator and/or onsite generating unit.

- The waste physically or chemically is unstable.

Waste generated at T Plant Complex is characterized before transfer to another TSD unit.

\subsection{NOTIFICATION REQUIREMENTS PERTAINING TO LAND DISPOSAL RESTRICTIONS FOR DEBRIS}

If the waste generated by $T$ Plant Complex is subject to LDR and meets the applicable treatment standards, a notification and a certification stating that the waste meets all applicable treatment standards will be submitted to the receiving unit. If the waste does not meet applicable treatment standards, a notification stating this fact, the dangerous waste number $(\mathrm{s})$, the constituent composition of the waste for constituents that do not meet the standards, and the treatment standards applicable to each constituent are 
WHC-SD-EN-WAP-005, ReV. 0

provided. Sections 5.3 .1 and 5.3.2 describe the notification requirements

that will be met for debris and for other waste streams.

\subsubsection{Notification Requirements for Debris}

A one-time notification will be provided to the EPA and Ecology for debris that is treated by an extraction or destruction technology identified in 40 CFR 268.45. The notification will include the following information:

- The name and location of the TSD unit receiving the treated debris

- A description of the dangerous debris as originally generated, including applicable waste numbers

- The technology used to treat the debris

- Records, including a certification, sufficient to document that decontamination was appropriately conducted and the technology-specific performance standards were achieved.

If a treatment technology in 40 CFR 268.45 is used, regulatory pre-notification and approval of the treatment method is not required. In addition, if the technology-specific performance standards are achieved, sampling to confirm treatment typically is not required (EPA 1994).

Notifications will be updated when any of the following changes are made.

- The debris is transferred to a different TSD unit.

- A different type of debris is treated.

- A different treatment technology is used.

Records of treatment/decontamination operations, certifications, and notifications will be maintained on the Hanford Facility. In addition, records of data on the success of treatment and associated key decontamination and/or treatment operating parameters are maintained. Before disposal of waste debris, a certification that the waste meets all applicable treatment standards will be prepared and maintained on file at the T Plant Complex. Notifications that are provided to the EPA and Ecology for treated debris also are maintained on file.

\subsubsection{Notification Requirements for Waste Streams}

Characterization information for the waste streams other than debris is provided to other TSD units that receive the waste. Analytical characterization data, necessary process knowledge, and LDR information will accompany the waste. The following LDR related information is provided to the receiving unit:

- Waste numbers

- The corresponding treatment standard 
WHC-SD-EN-WAP-005, Rev. 0

1 - The waste tracking identification number associated with the waste

2

- Available waste analysis and process knowledge.

4 
WHC-SD-EN-WAP-005, Rev. 0

\subsection{QUALITY ASSURANCE AND QUALITY CONTROL}

The following discussion presents the objectives of the $Q A$ and $Q C$ program that support the sampling and analysis of $\mathrm{T}$ Plant Complex waste.

\subsection{QUALITY ASSURANCE AND QUALITY CONTROL OBJECTIVES}

The primary purpose of waste testing is to ensure that the waste is properly characterized in compliance with WAC 173-303-300. Waste testing also is performed to ensure the safe management of waste being treated, stored, and/or transferred to another TSD unit. Testing ensures proper designation of waste accepted for storage or verification, and adequate characterization of waste generated during operational activities. To accomplish these goals, the $Q A / Q C$ program must ensure that chemical and physical analysis of representative samples of the waste that is treated or stored is of adequate quality.

The objectives of the QA/QC program are two-fold. The first objective is to control and characterize any errors associated with the data. The QA activities, such as the inspection of transfer papers before waste acceptance and use of standard methods for collecting samples, are intended to 1 imit the introduction of error. The $Q C$ activities, such as the collection of duplicate samples and the inclusion of blanks in sample sets, are intended to provide the information required to characterize errors in the data. Other QC activities ensure that the specified methods are followed and that the $Q A$ information needed for characterizing error is obtained.

The second $Q A / Q C$ objective is to illustrate that waste testing has been performed according to specifications in this waste analysis plan. These $Q A / Q C$ activities will include the following.

- Field inspections--performed by the appropriate T Plant Complex personnel and a member of the $T$ Plant Complex compliance group, depending on the activity. The inspections are visual examinations but could include radiologic measurements of containers and equipment. The purpose of these inspections is to verify that sampling is being performed properly (i.e., according to the specific guideline, specification, or method for the activity) and is successfully completed.

- Field testing--performed by trained sampling personnel with oversight by the appropriate $\mathrm{T}$ Plant Complex personnel according to specified methods. The purpose of field testing is to ensure that the waste received is labeled properly and designated. Field testing might include tests such as $\mathrm{pH}$ sampling, polychlorinated biphenyl and chlorinated compound screening, water reactivity, or oxidizing/reducing agent screening.

- Laboratory analyses--performed by onsite and offsite laboratories on samples of waste. The purpose of the laboratory analyses is 
WHC-SD-EN-WAP-005, Rev. 0

to demonstrate acceptable precision, accuracy, and representativeness of the data.

- Instrument calibration--maintain records of calibration of all instruments used to perform surveying, field testing, and laboratory analyses to demonstrate that instruments are within appropriate operating ranges to ensure data quality.

\subsection{SAMPLING, COLLECTION, AND ANALYTICAL OBJECTIVES}

The sampling objectives and data collection and analytical objectives are described in this section.

\subsubsection{Sampling Objectives}

Data quality objectives (DQOS) for the waste sampling and data analyses are as follows:

- Characterize the waste for purposes of designation and safe management

- Verify whether waste accepted for treatment or storage meets the waste characterization provided by the offsite generator and/or onsite generating unit

- Determine if waste accepted for storage or treatment meets the requirements of $\mathrm{T} \mathrm{Plant}$ Complex waste acceptance criteria

- Ensure waste samples are representative of the contents of the containers and tanks at the time the samples were taken

- Determine if waste accepted for characterization is regulated by WAC 173-303

- Determine if the waste to be transferred to another TSD unit meets the requirements of the unit's waste acceptance criteria

- Determine if treatment objectives have been achieved.

\subsubsection{Data Collection and Analytical objectives}

The acquired data need to be scientifically sound, of known quality, and thoroughly documented. The DQOs for the data collection and analysis are consistent with the DQOs specified in the Hanford Analytical Services Quality Assurance Plan (DOE/RL-94-55).

The data for chemical analyses accepted from onsite and offsite laboratories must meet the quality level described in the Hanford Analytical Services Quality Assurance Plan (DOE/RL-94-55). 


\subsection{FIELD QUALITY ASSURANCE AND QUALITY CONTROL}

Field QA/QC checks will be established by both qualitative documentation of sampling events and by submitting $Q A / Q C$ samples to the analytical

laboratory. Documentation of field sampling activities will include the following:

- Chain-of-custody use

- Sample holding times

- Sample preservation

- Sampling equipment decontamination procedures

- Field log documentation.

Field QC procedures involve taking additional samples and sending them to the analytical laboratory. Quantitative QC samples that are taken at each sampling event include trip blanks, equipment blanks, and field duplicates (DOE/RL-94-55). Each of these field QC samples is collected at approximately 5 percent of the total number of field samples taken for each matrix.

\subsection{LABORATORY QUALITY ASSURANCE AND QUALITY CONTROL}

The quality of analytical data to be maintained by the analytical laboratories is defined by compliance with the Hanford Analytical Services Quality Assurance Plan (DOE/RL-94-55).

Before commencement of the analytical work, the laboratory will submit its QA plan for approval (DOE/RL-94-55). At a minimum, an acceptable plan must address the following:

- Sample custody and management practices

- Analytical methods

- Sample preparation and analytical procedures

- Instrument maintenance and calibration procedures

- InternaT QA/QC measures including the use of method blanks

- Sample preservatives

- Other requirements if specified. 
WHC-SD-EN-WAP-005, Rev. 0

1

2

3

4

5

This page intentionally left blank. 
WHC-SD-EN-WAP-005, Rev. 0

\subsection{RECORDKEEPING}

This section describes recordkeeping, including waste analysis plan records, land disposal restriction records, and waste analysis plan maintenance and revision.

\subsection{WASTE ANALYSIS PLAN RECORDS}

This waste analysis plan is maintained by T Plant Complex. All documents referenced in the waste analysis plan except for the laboratory documents, which are maintained by the laboratories, also are maintained with the waste analysis plan as part of the $T$ Plant Complex operating record.

The records associated with the waste analysis plan are maintained as part of the operating record. These records are as follows:

- Description and quantity of each dangerous or mixed waste managed and the method(s) and date(s) of treatment are maintained in accordance with WAC 173-303-380 and 40 CFR 264, Appendix I. Offsite generators and/or onsite generating units maintain their sampling and analysis records, and $\mathrm{T} P 1$ ant Complex personnel can request copies of this information. Analytical data submitted with waste transfers are maintained with the waste descriptions and transfer papers.

- Waste manifests and onsite waste tracking records, describing the types and quantities of waste, are maintained as part of the permanent record at $\mathrm{T}$ Plant Complex.

- Location of each dangerous or mixed waste stored within T Plant Complex and the quantity at each location are documented and maintained. Transfers are documented on onsite waste tracking records and provided to other TSD units receiving the waste.

- Waste analyses and designation records for T Plant Complex-generated waste are maintained, as appropriate, for the following:

- Waste generated at T Plant Complex from the decontamination activities at $\mathrm{T}$ Plant Complex

- Waste characterized (identified and/or verified) at T Plant Complex as a service for other organizations

- Waste generated from maintenance activities at T Plant Complex

- Waste resulting from a spill or leak.

- Records and results of waste analyses and trial tests required to manage the dangerous or mixed waste properly (including any supplied analytical and test data) 
- The LDR information contained in the notices (except the manifest number), and certifications and demonstrations, if applicable, required under 40 CFR 268.7 .

As required, results of these analyses are provided to other TSD units subsequently receiving the waste for further treatment, storage, and/or disposal.

\subsection{LAND DISPOSAL RESTRICTION RECORDS}

Records related to treatment of waste subject to LDR requirements are maintained by the Hanford Facility as required by 40 CFR 264.73(b)(10) and

(12). Records include but are not necessarily limited to the following:

- The applicable notice and certification required by 40 CFR 268.7 (a) or 40 CFR 268.7(b)

- Records of waste placed in land disposal units under an extension to the effective date of any LDR granted pursuant to 40 CFR 268.5

- Records of waste placed in land disposal units under a petition granted pursuant to 40 CFR 268.6.

An onsite waste tracking system is in place to document the transfer of waste subject to LDRs.

\subsection{WASTE ANALYSIS PLAN MAINTENANCE AND REVISION}

The waste analysis plan is maintained as a controlled document under the existing guidelines. Documents are maintained for a minimum period of 5 years per WAC 173-303.

The waste analysis plan will be revised under the following circumstances:

- Test methods are changed

- Waste streams or process operations are modified, thus requiring a change in the parameters to be tested

- Regulations are changed that affect the plan.

Revisions to the plan will be made under the direction of T Plant Complex personnel. 
DOE/RL-88-21, Hanford Facility Dangerous Waste Part A Permit Application, $T$ Plant Complex, updated periodically, U.S. Department of Energy, Richland Operations Office, Richland, Washington.

DOE/RL-90-39, Hanford Facility Dangerous Waste Permit Application, Double-Shell Tank System, U.S. Department of Energy, Richland Operations office, Richland, Washington.

DOE/RL-94-55, Hanford Analytical Services Quality Assurance Plan, Rev. 0, Department of Energy, Richland Operations Office, Richland, Washington.

Ecology, 1994, Dangerous Waste Portion of the Resource Conservation and Recovery Act Permit for the Treatment, Storage, and Disposal of Dangerous Waste, August 29, 1994, Permit No. WA7890008967, Washington State Department of Ecology, 01ympia, Washington.

EPA, 1986, Test Methods for Evaluating Solid Waste, Physical/Chemical Methods, SW-846, 3rd edition, 1986, as amended, U.S. Environmental Protection Agency, Washington, D.C.

EPA, 1994, "Proposed Site Policy for Contaminated Equipment," letter from Michael Gearheard, Chief, Waste Management Branch, US EPA Region 10 and Dru Butler, Manager, Nuclear Waste Program, Washington State Department of Ecology, to Jim Rasmussen, Acting Program Manager, Office of Environmental Assurance, Permits, and Policy, U.S. Department of Energy, Richland Operation Office, dated August 31, 1994.

WHC, 1994, T Plant Safety Analysis Report, WHC-SD-CP-SAR-007, Rev. 1B, West inghouse Hanford Company, Richland, Washington. 
WHC-SD-EN-WAP-005, ReV, 0

$$
\begin{aligned}
& 1 \\
& 2 \\
& 3 \\
& 4 \\
& 5
\end{aligned}
$$

This page intentionally left blank. 
WHC-SD-EN-WAP-005, Rev. 0

1
2
3
4

ATTACHMENT 1

ANALYTICAL PARAMETERS, METHODS, AND RATIONALE FOR WASTE 
WHC-SD-EN-WAP-005, Rev. 0

This page intentionally left blank. 
Analytical Parameters, Methods, and Rationale for Waste. (sheet 1 of 6)

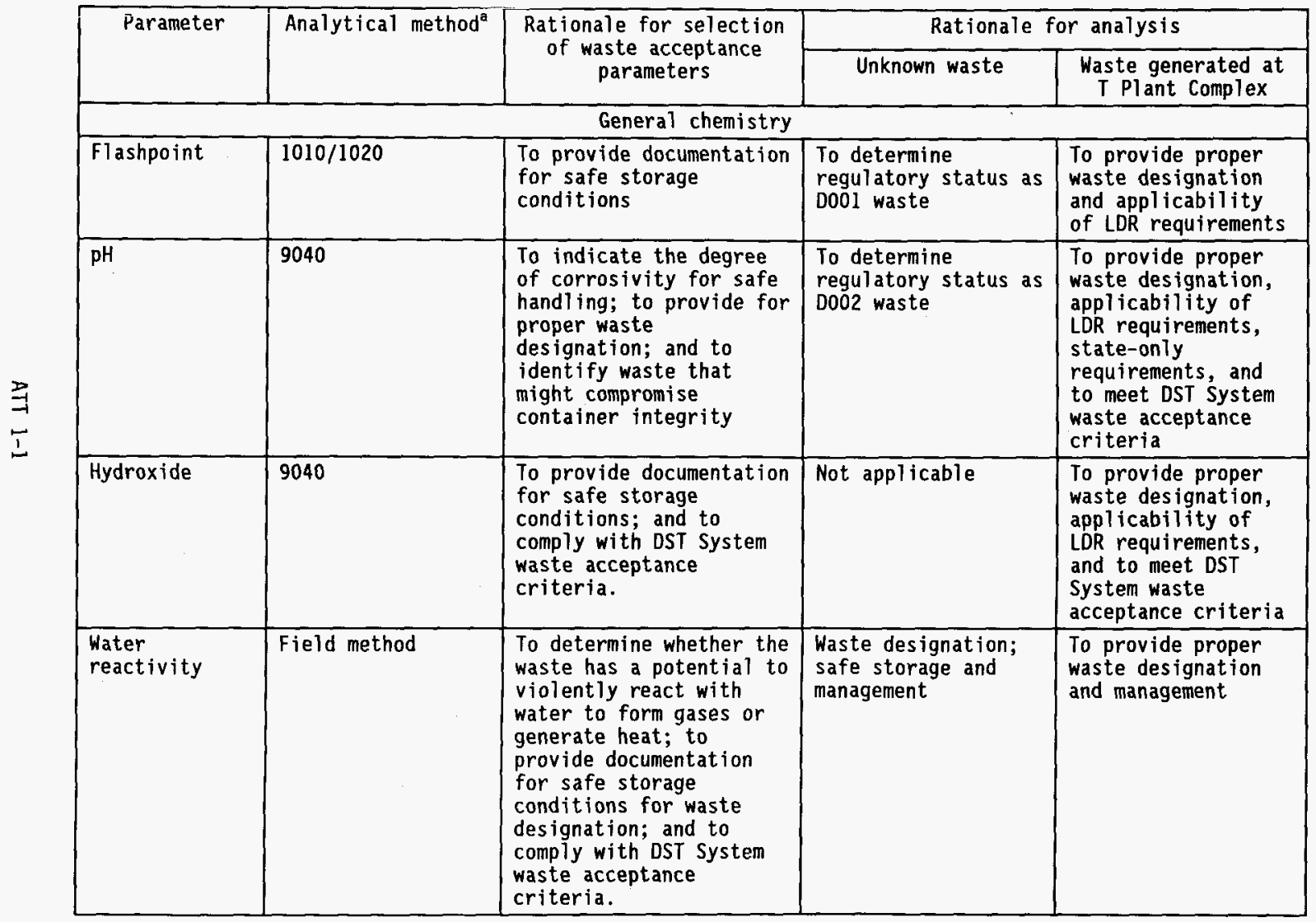


Analytical Parameters, Methods, and Rationale for Waste. (sheet 2 of 6)

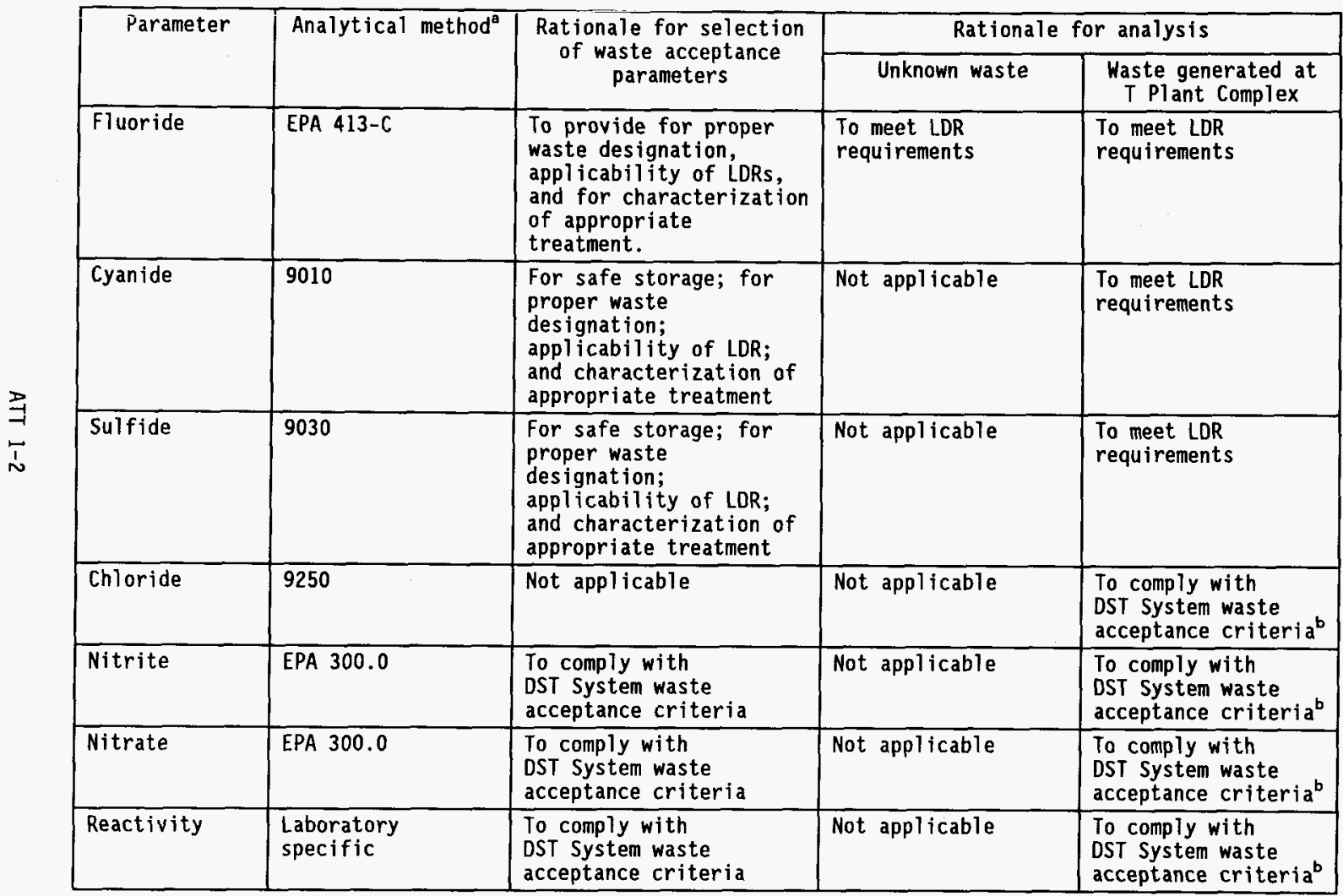


Analytical Parameters, Methods, and Rationale for Waste. (sheet 3 of 6 )

\begin{tabular}{|c|c|c|c|c|}
\hline \multirow[t]{2}{*}{ Parameter } & \multirow[t]{2}{*}{ Analytical method ${ }^{2}$} & \multirow{2}{*}{$\begin{array}{c}\text { Rationale for selection } \\
\text { of waste acceptance } \\
\text { parameters }\end{array}$} & \multicolumn{2}{|c|}{ Rationale for analysis } \\
\hline & & & Unknown waste & $\begin{array}{l}\text { Waste generated at } \\
\mathrm{T} \text { Plant Complex }\end{array}$ \\
\hline \multicolumn{5}{|c|}{ Organic analyses } \\
\hline PCBS & 8080 & $\begin{array}{l}\text { To determine proper } \\
\text { waste designation for } \\
\text { management of waste in } \\
\text { accordance with the } \\
\text { Toxic Substance Control } \\
\text { Act of } 1976 \text { and } \\
\text { HAC } 173-303 \text {. }\end{array}$ & $\begin{array}{l}\text { To meet LDR } \\
\text { requirements }\end{array}$ & $\begin{array}{l}\text { To determine proper } \\
\text { waste designation; } \\
\text { to meet LDR } \\
\text { requirements }\end{array}$ \\
\hline $\begin{array}{l}\text { Total organic } \\
\text { carbon }\end{array}$ & 9060 & $\begin{array}{l}\text { To comply with } \\
\text { DST System waste } \\
\text { acceptance criteria; } \\
\text { applicability of LDR }\end{array}$ & $\begin{array}{l}\text { To determine and } \\
\text { applicability of LDR } \\
\text { requirements }\end{array}$ & $\begin{array}{l}\text { To comply with } \\
\text { DST System waste } \\
\text { acceptance } \\
\text { criteriab; } \\
\text { applicability to } \\
\text { LDR }\end{array}$ \\
\hline $\begin{array}{l}\text { Semivolatile } \\
\text { organic } \\
\text { compounds }\end{array}$ & $1311 / 8270$ & $\begin{array}{l}\text { To determine proper } \\
\text { waste designation, } \\
\text { applicability of LoRs, } \\
\text { and characterization of } \\
\text { appropriate treatment. }\end{array}$ & $\begin{array}{l}\text { To determine } \\
\text { regulatory status to } \\
\text { meet LDR } \\
\text { requirements }\end{array}$ & $\begin{array}{l}\text { To provide proper } \\
\text { waste designation } \\
\text { and applicability } \\
\text { of LDR requirements }\end{array}$ \\
\hline $\begin{array}{l}\text { Chlorinated } \\
\text { herbicides }\end{array}$ & 8150 & Not applicable & Not app Ticable & $\begin{array}{l}\text { To provide proper } \\
\text { waste designation } \\
\text { and applicability } \\
\text { to state-only } \\
\text { requirements. }\end{array}$ \\
\hline
\end{tabular}


Analytical Parameters, Methods, and Rationale for Waste. (sheet 4 of 6)

\begin{tabular}{|c|c|c|c|c|}
\hline \multirow[t]{2}{*}{ Parameter } & \multirow[t]{2}{*}{ Analytical method } & \multirow{2}{*}{$\begin{array}{c}\text { Rationale for selection } \\
\text { of waste acceptance } \\
\text { parameters }\end{array}$} & \multicolumn{2}{|c|}{ Rationale for analysis } \\
\hline & & & Unknown waste & $\begin{array}{l}\text { Waste generated at } \\
\mathrm{T} \text { Plant Complex }\end{array}$ \\
\hline \multicolumn{5}{|c|}{ Inorganic analyses } \\
\hline Arsenic & $1311 / 6010$ & $\begin{array}{l}\text { To provide for proper } \\
\text { waste designation, } \\
\text { applicability of LDRs, } \\
\text { and for characterization } \\
\text { of appropriate } \\
\text { treatment. }\end{array}$ & $\begin{array}{l}\text { To determine } \\
\text { regulatory status as } \\
\text { toxicity } \\
\text { characteristic waste }\end{array}$ & $\begin{array}{l}\text { To provide proper } \\
\text { waste designation } \\
\text { and applicability } \\
\text { of LDR requirements }\end{array}$ \\
\hline Barium & $1311 / 6010$ & $\begin{array}{l}\text { To provide for proper } \\
\text { waste designation, } \\
\text { applicability of LoRs, } \\
\text { and for characterization } \\
\text { of appropriate } \\
\text { treatment. }\end{array}$ & $\begin{array}{l}\text { To determine } \\
\text { regulatory status as } \\
\text { toxicity } \\
\text { characteristic waste }\end{array}$ & $\begin{array}{l}\text { To provide proper } \\
\text { waste designation } \\
\text { and applicability } \\
\text { of LDR requirements }\end{array}$ \\
\hline Chromium & $1311 / 6010$ & $\begin{array}{l}\text { To provide for proper } \\
\text { waste designation, } \\
\text { applicability of LDRs, } \\
\text { and for characterization } \\
\text { of appropriate } \\
\text { treatment. }\end{array}$ & $\begin{array}{l}\text { To determine } \\
\text { regulatory status as } \\
\text { toxicity } \\
\text { characteristic waste }\end{array}$ & $\begin{array}{l}\text { To provide proper } \\
\text { waste designation } \\
\text { and app? icability } \\
\text { of LDR requirements }\end{array}$ \\
\hline Lead & $1311 / 6010$ & $\begin{array}{l}\text { To provide for proper } \\
\text { waste designation, } \\
\text { applicability of LDRs, } \\
\text { and for characterization } \\
\text { of appropriate } \\
\text { treatment. }\end{array}$ & $\begin{array}{l}\text { To determine } \\
\text { regulatory status as } \\
\text { toxicity } \\
\text { characteristic waste }\end{array}$ & $\begin{array}{l}\text { To provide proper } \\
\text { waste designation } \\
\text { and applicability } \\
\text { of LDR requirements }\end{array}$ \\
\hline
\end{tabular}


Analytical Parameters, Methods, and Rationale for Waste. (sheet 5 of 6)

\begin{tabular}{|c|c|c|c|c|}
\hline \multirow[t]{2}{*}{ Parameter } & \multirow[t]{2}{*}{ Analytical method ${ }^{a}$} & \multirow{2}{*}{$\begin{array}{c}\text { Rationale for selection } \\
\text { of waste acceptance } \\
\text { parameters }\end{array}$} & \multicolumn{2}{|c|}{ Rationale for analysis } \\
\hline & & & Unknown waste & $\begin{array}{l}\text { Waste generated at } \\
\text { T Plant Complex }\end{array}$ \\
\hline Mercury & $1311 / 7470$ & $\begin{array}{l}\text { To provide for proper } \\
\text { waste designation, } \\
\text { applicability of LDRs, } \\
\text { and for characterization } \\
\text { of appropriate } \\
\text { treatment. }\end{array}$ & $\begin{array}{l}\text { To determine } \\
\text { regulatory status as } \\
\text { toxicity } \\
\text { characteristic waste }\end{array}$ & $\begin{array}{l}\text { To provide proper } \\
\text { waste designation } \\
\text { and applicability } \\
\text { of LDR requirements }\end{array}$ \\
\hline Selenium & $1311 / 6010$ & $\begin{array}{l}\text { To provide for proper } \\
\text { waste designation, } \\
\text { applicability of LDRs, } \\
\text { and for characterization } \\
\text { of appropriate } \\
\text { treatment. }\end{array}$ & $\begin{array}{l}\text { To determine } \\
\text { regulatory status as } \\
\text { toxicity } \\
\text { characteristic waste }\end{array}$ & $\begin{array}{l}\text { To provide proper } \\
\text { waste designation } \\
\text { and applicability } \\
\text { of LDR requirements }\end{array}$ \\
\hline Nickel & 6010 & $\begin{array}{l}\text { To provide for proper } \\
\text { waste designation, } \\
\text { applicability of LDRs, } \\
\text { and for characterization } \\
\text { of appropriate } \\
\text { treatment. }\end{array}$ & $\begin{array}{l}\text { To meet LDR } \\
\text { requirements }\end{array}$ & $\begin{array}{l}\text { To meet LDR } \\
\text { requirements }\end{array}$ \\
\hline Vanadium & 6010 & $\begin{array}{l}\text { To provide for proper } \\
\text { waste designation, } \\
\text { applicability of LDRs, } \\
\text { and for characterization } \\
\text { of appropriate } \\
\text { treatment. }\end{array}$ & $\begin{array}{l}\text { To meet } L D R \\
\text { requirements }\end{array}$ & $\begin{array}{l}\text { To meet LDR } \\
\text { requirements }\end{array}$ \\
\hline
\end{tabular}


Analytical Parameters, Methods, and Rationale for Waste. (sheet 6 of 6 )

\begin{tabular}{|c|c|c|c|c|}
\hline \multirow[t]{2}{*}{ Parameter } & \multirow[t]{2}{*}{ Analytical method ${ }^{a}$} & \multirow{2}{*}{$\begin{array}{c}\text { Rationale for selection } \\
\text { of waste acceptance } \\
\text { parameters }\end{array}$} & \multicolumn{2}{|c|}{ Rationale for analysis } \\
\hline & & & Unknown waste & $\begin{array}{l}\text { Waste generated at } \\
\mathrm{T} \text { Plant Complex }\end{array}$ \\
\hline Zinc & 6010 & $\begin{array}{l}\text { To provide for proper } \\
\text { waste designation, } \\
\text { applicability of LDRs, } \\
\text { and for characterization } \\
\text { of appropriate } \\
\text { treatment. }\end{array}$ & $\begin{array}{l}\text { To meet LDR } \\
\text { requirements }\end{array}$ & $\begin{array}{l}\text { To meet } L D R \\
\text { requirements }\end{array}$ \\
\hline $\begin{array}{l}\text { State toxicity } \\
\text { criterion }\end{array}$ & WAC $173-303-100(5)$ & Not applicable & Not applicable & $\begin{array}{l}\text { To provide proper } \\
\text { waste designation } \\
\text { and applicability } \\
\text { to state-only } \\
\text { requirements. }\end{array}$ \\
\hline
\end{tabular}

EPA 1986, unless otherwise noted.

DOE/RL-90-39.

DST = double-shell tank.

LDR = land disposal restriction.

$P C B=$ polychlorinated biphenyls. 
WHC-SD-EN-WAP-005, Rev. 0

ref. DOE/RL-95-36, Rev. 0

\section{ATTACHMENT 2}

FIELD AND LABORATORY ANALYTICAL METHODS

FOR VERIFICATION FINGERPRINT SAMPLING 
WHC-SD-EN-WAP-005, Rev. 0

ref. DOE/RL-95-36, Rev. 0

This page intentionally left blank. 
Field and Laboratory Analytical Methods

for Verification Fingerprint Sampling.

\begin{tabular}{|c|c|}
\hline Parameters & Analytical method/instrumentation \\
\hline \multicolumn{2}{|r|}{ Field analyses } \\
\hline Corrosivity & $\mathrm{pH}$ paper (within \pm 2.5 units) or $\mathrm{pH}$ meter \pm 1 unit \\
\hline Water reactivity & Physical changes upon water addition \\
\hline $\begin{array}{l}\text { Oxidizing agent } \\
\text { Reducing agent }\end{array}$ & $\begin{array}{l}\text { Color change upon potassium jodide (KI)addition } \\
\text { Color change upon starch/water/iodide addition }\end{array}$ \\
\hline Chlorinated compounds & Presence or absence indicated by chlorine test kit \\
\hline \multicolumn{2}{|r|}{ Laboratory analyses } \\
\hline $\begin{array}{l}\frac{\text { Listed wastel }}{\text { Waste Constituents }} \\
\text { P or U listed waste } \\
\text { F001-F003, F005 } \\
\text { F004 }\end{array}$ & $\begin{array}{l}\text { EPA-approved analytical test methods' } \\
\text { Process knowledge } \\
\text { SW-846 Method } 8240 \text {; extraction will vary depending } \\
\text { on whether waste is aqueous, sludge, or solid } \\
\text { SW- } 846 \text { Method } 8270 \text {; extraction will vary depending } \\
\text { on whether waste is aqueous, sludge, or solid }\end{array}$ \\
\hline $\begin{array}{l}\frac{\text { Toxicity }}{\text { characteristics waste }} \\
\text { D004-D008, D010-D011 } \\
\text { D009 } \\
\text { D012-D043 }\end{array}$ & $\begin{array}{l}\text { EPA-approved analytical test methods }{ }^{2} \\
\text { SW-846 Method } 1311 \text { (TCLP) } / 6010 \\
\text { SW-846 Method } 1311 \text { (TCLP)/7470 } \\
\text { SW-846 Method } 1311 \text { (TCLP) } / 8240,8270 \text {, and } 8080\end{array}$ \\
\hline Carrosivity & SW-846 Method $9040^{1}$ \\
\hline Ignitability & SW-846 Method 1010 or $1020^{1}$ \\
\hline $\begin{array}{l}\text { Reactivity: } \\
\text { Sulfides }\end{array}$ & $\begin{array}{l}\text { EPA-approved analytical test methods }{ }^{1} \\
\text { SW-846 Method } 9030\end{array}$ \\
\hline $\begin{array}{l}\text { Total and amenable } \\
\text { cyanides }\end{array}$ & SW-846 Method 9010 \\
\hline
\end{tabular}

38

39

\footnotetext{
EPA 1986.
} 


\section{DISTRIBUTION SHEET}

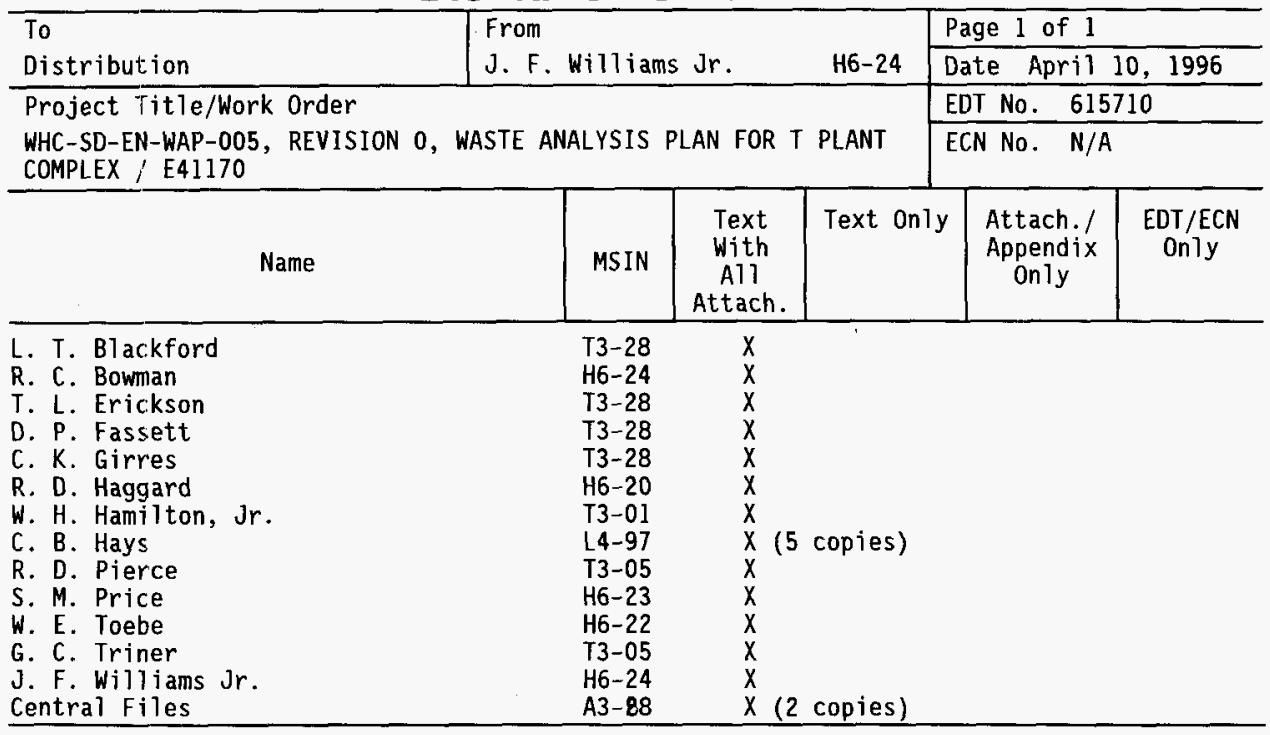

